Nadwa : Jurnal Pendidikan Islam

Vol. 12, Nomor 1 Tahun 2018

Accredited by Ristekdikti based on Decree No. 51/E/KPT/2017

\title{
Model Pendidikan Akhlaq Santri di Pesantren dalam Meningkatkan Akhlaq Siswa Di Kabupaten Bireuen
}

\author{
Muhammad Rizal \\ Universitas Almuslim Bireuen Aceh \\ abizal2013@gmail.com \\ Muhammad Iqbal \\ Universitas Almuslim Bireuen Aceh \\ Najmuddin \\ Universitas Almuslim Bireuen Aceh
}

\begin{abstract}
The research was conducted begins on government policy on implementation of Islamic sharia in Aceh. Pesantren's education pattern has emphasized more on strengthen professional fields simultanously and strengthenIislamic scope dan akhlakul karimah (character education). Qualitative method was used in this study with descriptive approach. Result showed that curriculum currently used in pesantren is refer to dayah salafi (traditional pesantren) in Aceh, which used Kitab as main source of knowledge in teaching process. While media used in teaching process were Arab's Kitab, video, playback of religious lectures, and wall magazines. The methode used in teaching process were advice, teacher exemplary, teaching and counseling, habituation of religious practice, motivation straightening, coordination with santri's parents, and coordination with dayah's stakeholder, morals coaching output, and reward and punishment methods.
\end{abstract}

Key Word: Model, Morals Education, Pesantren.

\begin{abstract}
Abstrak
Penelitian dilakukan berawal dari kebijakan Pemerintah terhadap implementasi syariat Islam di Aceh. Pola pendidikan pesantren memiliki tradisi dan kultur akademik yang lebih menekankan pada penguatan bidang profesional secarasi simultan, serta penguatan pada bidang-bidang keislaman dan pendidikan akhlakul karimah. Penulis menggunakan metode penelitian kualitatif dengan pendekatan deskriptif.. Hasil penelitian menunjukkan bahwa kurikulum yang berlaku di pesantren semuanya mengacu kepada kurikulum dayah salafi di Aceh dengan menjadikan kitab sebagai sumber utama dalam proses belajar mengajar. Media yang digunakan pada proses pembelajaran adalah kitab-kitab Arab, tayangan vidio, pemutaran ceramah agama dan pemanfaatan madding. Sedangkan metode yang digunakan meliputi metode nasehat, keteladanan guru, bimbingan dan pendampingan, praktek dan pembiasaan amalan ibadah, pelurusan motivasi, koordinasi dengan wali santri, koordinasi dengan stakeholder dayah, out put pembinaan akhlak dan reward serta punisment.

Kata Kunci: Model; Pendidikan; Akhlak; Pesantren.;
\end{abstract}

IS SN 1979-1739 (P) ; ISSN 2502-8057 (E).

(9) 2018 Nadwa : Jurnal Pendidikan Islam | UnN Walisongo.

Accredited by Ristekdikti based on Decree Na 51/E/KPT/2017

http:/joumal.wal isongo.ac.id/index.php'nadwa 


\section{Pendahuluan}

Dinamika kehidupan beragama di Aceh saat ini sedang mendapat perhatian yang besar dari berbagai kalangan, terutama dalam kaitan Aceh sebagai satu-satunya contoh daerah yang melaksanakan syariat Islam secara komprehensif di Indonesia.1 Penetapan Aceh sebagai daerah yang menerapkan syariat Islam tentu saja menimbulkan tanggung jawab yang tidak biasa dibandingkan dengan tugas kenegaraan lainnya, sebab syariat Islam selalu dikaitkan dengan moralitas manusia dimuka bumi khususnya di Aceh.Sejalan dengan hal ini, untuk tercapainya tujuan tersebut dibutuhkan peran dan tanggung jawab ulama sebagai penggerak Lembaga Pendidikan Dayah (pesantren) di Aceh dan cendikiawan/akademisi Islam sebagai penggerak Perguruan Tinggi Islam dalam menjabarkan makna akhlak atau karakter manusia agar dapat dipahami dan diamalkan dalam kehidupan beragama di Aceh.2

Aceh merupakan bagian dari Negara Kesatuan Republik Indonesia. Indonesia dikenal sebagai sebuah negara besar yang memiliki penduduk ratusan juta jiwa. Indonesia juga adalah negara yang mayoritas penduduknya memeluk agama Islam. Menurut sebuah perhitungan manusia Muslim, Indonesia adalah jumlah pemeluk agam Islam terbesar di dunia. Jika dibandingkan dengan negara-negara Muslim lainnya, maka penduduk Muslim Indonesia dari segi jumlah tidak ada yang menandingi.

Kondisi ini sangat kontradiktif dengan kualitas dan kekuatan SDM umat Islam, dibandingkan dengan umat dari agama lainnya, baik dari segi ideologi, politik, ekonomi dan budaya, secara realitas membuktikan lain,jumlah manusia Muslim yang besar tersebut ternyata tidak mamiliki kekuatan sebagaimana seharusnya yang dimiliki. Kualitas manusia Muslim Indonesia masih berada di tingkat menengah ke bawah. Memang ada satu atau dua orang yang menonjol, hanya saja kemenonjolan tersebut tidak mampu menjadi lokomotif bagi rangkaian gerbong manusia Muslim lainnya. Apalagi bila berbicara tentang kekompakan dan

1Kamaruzzaman Bustaman-Ahmad, "The Application of Islamic Law in Indonesia; The Case Study of Aceh",International Journal Of IndonesianIslam-Australia. Vol 01, Number 01. (2007): 141

2Musliadi. Peran Dan Tanggung Jawab Ulama Dayah Dan Akademisi Dalam Mencegah Kekerasan Di Aceh, (Banda Aceh; 2012), 3 
loyalitas terhadap agama, sesama dan kaum fakir miskin. Sebagian besar dari manusia Muslim yang ada masih berkutat untuk memperkaya diri, kelompok dan pengurus partainya sendiri.3

Fenomena yang paradoks ini secara tidak langsung merupakan hasil dari pola pendidikan Islam selama ini. Pola dan model pendidikan Islam yang dikembangkan selama ini masih berkutat pada pemberian materi yang tidak aplikatif dan praktis. Bahkan sebagian besar model dan proses pendidikannya terkesan "asal-asalan" atau tidak professional. Selain itu, pendidikan Islam di Indonesia negara tercinta mulai tereduksi oleh nilai-nilai negatif gerakan dan proyek modernisasi yang secara nyata bertentangan dengan ajaran Islam itu sendiri.4

Berbicara tentang Pendidikan Islam di Indonesia tidak terlepas dari sistem pendidikan berbasis boarding school (Dayah/ pesantren) dannon boarding school (SMA/MA sampai jenjang Perguruan Tinggi).Konteks pendidikan pesantren di Indonesia bukan hanya membahas pendidikan Islam secara umum, namun pesantren memiliki tradisi dan kultur akademik yang berbeda dengan karakteristik pendidikan Islam pada umumnya. Selain itu, dalam pendidikan pesantren terdapat interaksi antara peserta didik dengan pendidik dan pengelola asrama memungkinkan terciptanya kultur akademik yang kompetitif, dan keteladanan dalam pengamalan ajaran Agama Islam.

Pola pendidikan yang selama ini dijalankan di lembaga pendidikan Pesantren Modern khususnya di Aceh memiliki 5 (lima) keunggulan. Pertama, pendidikan di Pesantren Modernmenamkan nilai-nilai iman yang kuat dan kebencian terhadap musuh Allah dan Rasullah yaitu orang-orang kafir yang memusuhi Islam (kafir al-harby), kedua, Pendidikan di Pesantren Modern menanamkan "nilai-nilai karakter". Bahasa Alqur'an nilai-nilai karakter ini disebut dengan Ruhamâ'u bainahum (budaya toleransi dan kasih sayang sesama Muslim). Ketiga, Pendidikan di Pesantren Modernmenanamkan nilai-nilai ibadah.

3 Ahmad Naufah. Ikhtiar Pelajar dan Santri Menjaga Degradasi Moral, (Jokjakarta; 2011), 3

4 Syahrin Harahap. Perguruan Tinggi Islam di Era Globalisasi, (Yokyakarta: Tiara Wacana, 1998), 75 
Dalam bahasa Alquran nilai-nilai ibadah ini disebut dengan "selalu rukuk dan sujud" dalam arti sangat mantap melalukan penghambaan kepada Allah. Keempat, Pendidikan di Pesantren Modern selalu menanamkan kepada santrinya untuk selalu mencari keridhaan Allah, karena ridha Allah yang dicari, maka segala yang dilakukan disesuaikan dengan yang dikehendaki oleh Allah. Kelima, Pendidikan di Pesantren Modern dengan menanamkan nilai-nilai keteladanan. Bahasa Al-Qur'an disebutkan "Memperlihatkan bekas yang positif dari ibadahnya dalam kehidupan sehari-hari"..5

Hakikatnya lembaga pendidikan berbasis pesantren modern dan sekolah lain pada umumnya memiliki kesamaan pada kurikulum,yaitu mentransfer ilmu pengetahuan kepada peserta didiknya. Namun, perbedaannya hanya pada media pembelajaran dan metode yang diterapkan dalam proses belajar mengajar, sehingga jauh dari aplikasi nilai-nilai dari suatu ilmu pengetahuan yang diperolehnya.

Proses interaksi antara siswa dan guru hanya berlangsung di dalam ruang, ketika proses belajar mengajar. Namun, ketika proses belajar mengajar berakhir, maka proses interaksi siswa dan guru pun berakhir. Hal ini menyebabkan munculnya berbagai reaksi pada diri siswa, sebagai contoh kasus sering terjadinya tawuran antar-pelajar. Khusus di Kabupaten Bireuen sering terjadinya tawuran antar-pelajar SMA, salah satu kasus yaitu tawuran antar pelajar SMK Negeri 1 Bireuen dengan SMA Negeri 2 Bireuen yang terjadi pada bulan Februari 2015 yang lalu dan hampir setiap tahun selalu terjadi kasus-kasus tawuran antar SMK Negeri 1 dan SMA Negeri 2 Bireuen tersebut tanpa ada titik temu. Selain kasus tersebut, banyak siswa kedapatan merokok di area sekolah bahkan secara terang-terangan siswa merokok di depan gurunya ketika usai sekolah. Semua kasus tersebut berkaitan dengan akhlak siswa yang semakin hari semakin menurun.6

Berdasarkan hasil wawancara penulis dengan salah seorang tokoh ormas Dayah beliau menyebutkan bahwa "Pesantren masih tetap menjadi pilihan utama bagi sebagian besar masyarakat

5 Saifullah, "Kelebihan Pendidikan Berbasis Dayah", Serambi Indonesia, 27 Februari 2013, 7

6 Observasi Penulis pada tanggal 25 November 2015 
Aceh, terutama masyarakat yang tinggal di pelosok-pelosok desa. Para orang tua di daerah ini lebih banyak menyekolahkan anaknya di pesantren modern yang mengadopsi sistem boarding school daripada di sekolah umum. Pesantren Modern sampai saat ini masih menjadi pilihan utama bagi para orang tua dalam mendidik anak-anak mereka".7

Dengan demikian, dewasa ini sudah sepantasnya institusi pendidikan Islam memiliki kinerja yang produktif, efektif, transparan dan akuntabel. Di pihak lain, penerapan tata kelola yang bersih dan baik (clean and good governance) merupakan imbas positif dari demokratisasi pada level pemerintahan yang kemudian menjadi tuntutan di semua level organisasi, termasuk pada tingkat lembaga pendidikan. Sebab, secara tidak langsung, baik atau buruknya pengelolaan pendidikan akan berdampak pada layanan terhadap peserta didik di semua jenjang pendidikan dan menjadi penilaian tersendiri dari masyarakat. 8

Berdasarkan hasil wawancara dengan tokoh masyarakat setempat menyatakan bahwa "Untuk mendidik anak supaya mendapatkan ilmu pengetahuan agama yang luas serta mampu diaplikasikan dalam kehidupan sehari-hari lebih bagusnya anak dididik pada lembaga pendidikan pesantren modern dari pada di sekolah umum. Pola pendidikan pesantren menganut sistem boarding school yang mampu mengarahkan santrinya kepada pembinaan akhlak atau minimal si anak selalu melaksanakan shalat 5 waktu".9

Dalam aspek pembinan ahklak, pergeseran terjadi pada pandangan masyarakat tentang konsep karakter itu sendiri. Karakter di sini dipahami sebagai konsep tentang moral atau kebaikan atau baiknya sesuatu yang telah dikonstruksi oleh masyarakat. Penilaian yang dilakukan oleh masyarakat terhadap lembaga tersebut menjadi motor terhadap peningkatan mutu

7 Tu Bulkaini, Sekjend HUDA Aceh, Wawancara di Bireuen, 18 Oktober 2013

8 Husni Nasution, Arah Baru Pendidikan Islam di Indonesia, (Jakarta; Logos, 2001), 59

9Wawancara dengan Marzuki, salah seorang Dosen UMUSLIM, pada tanggal 26 November 2016 
lulusan dari lembaga pendidikan tersebut.10 Ditinjau dari proses pembelajaran yang dilaksanakan di lembaga pendidikan pesantren dan lembaga pendidikan nonpesantren terkoordinir dalam satu wadah kurikulum yang dikeluarkan oleh Kementerian Pendidikan dan Kebudayaan RI, namun realitanysa terjadi perbedaan karakter yang dihasilkan dari kedua lembaga tersebut.

Permasalahan yang menjadi titik berat pembahasan penelitian ini, lebih diprioritaskan kepada pola pembinaan ahklak yang diberlakukan di lembaga pesantren di Bireuen dalam pembinaan karakter siswa, baik yang berkaitan dengan kurikulum pembelajaran, media pembelajaran maupun metode pengajaran yang diterapkan dalam membinakarakter peserta didiknya.

\section{Strategi Pembinaan Ahklaq}

Strategi adalah cara untuk mencapai tujuan jangka panjang. Strategi adalah pendekatan secara keseluruhan yang berkaitan dengan pelaksanaan gagasan, perencanaan, dan eksekusi sebuah aktivitas dalam kurun waktu tertentu.11 Tantangan yang dihadapi oleh para penggerak dunia pendidikan saat ini semakin banyak, salah satunya adalah perubahan atmosfer dunia pendidikan yang sebagian besar dipengaruhi oleh adanya perkembangan teknologi yang akan terus terjadi.

Menurut Abdurrahman an-Nahlawi, metode pendidikan Islam adalah metode dialog, metode kisah Qurani dan Nabawi, metode keteladanan, metode aplikasi dan pengamalan, metode ibrah dan nasihat serta metode targhib dan tarhib. Berikut adalah beberapa metode yang bisa diterapkan dalam pembinaan akhlak, yaitu: 12

1. Metode dialog, adalah metode belajar yang menggunakan tanya jawab, apakah pembiacaraan itu antara dua orang atau lebih, dan mempunyai tujuan serta topik pembicaraan

10 Ajat Sudrajat, Pendidikan Agama Islam di Perguruan Tinggi Umum,(Yokyakarta; UNY Press), 102

11Omar Muhammad al-Toumy Al-Syaibany. Filsafat Pendidikan Islam, (terj. Hasan Langgulung), (Jakarta: Bulan Bintang, 1979), 78

12Abdurrahman An-Nahlawi, Ushulut Tarbiyah Islamiyah Wa Asalibiha fii Baiti wal Madrasati wal Mujtama'(terj), (Jakarta: Gema Insani Press, 1996), 61. 
tertentu.13 Atau penyampaian pelajaran dengan cara guru mengajukan pertanyaan dan murid menjawab.14 Rasulullah Saw menggunakan metode dialog dalam mendidik/mengajar sahabatnya. Dialog ada yang diawali dengan pertanyaan sahabat kepada Nabi dan adapula yang diawali dengan pertanyaan Rasulullah kepada sahabat.

2. Metode Kisah Qurani dan Nabawi, Dalam al-Quran banyak ditemukan kisah yang menceritakan kejadian masa lalu, kisah yang mempunyai daya tarik tersendiri dan tujuannya mendidik akhlak, kisah-kisah para Nabi dan Rasul sebagai pelajaran berharga. Selain itu kisah dalam al-Quran bertujuan mengkokohkan wahyu dan risalah para Nabi, memberi informasi terhadap agama yang dibawa para Nabi adalah berasal dari Allah dan mampu menghibur umat Islam yang sedang sedih atau tertimpa musibah. Metode mendidik akhlak melalui kisah akan memberi kesempatan bagi anak untuk berfikir, merasakan dan merenungi kisah tersebut, sehingga seolah ia ikut berperan dalam kisah tersebut. Adanya keterkaitan emosi anak terhadap kisah akan memberi peluang bagi anak untuk meniru tokoh-tokoh berakhlak baik dan berusaha meninggalkan perilaku tokoh-tokoh berakhlak buruk.

3. Metode Teladan, Muhammad bin Muhammad al-Hamid mengatakan pendidik itu besar dimata anak didiknya, apa yang dilihat dari gurunya akan ditirunya, karena murid akan meniru dan meneladani apa yang dilihat dari gurunya.15Keteladanan menjadi titik sentral dalam mendidik dan membina akhlak anak didik jika pendidik berakhlak baik, maka anak didiknya juga berakhlak baik, karena murid meniru gurunya, sebaliknya jika guru berakhlak buruk ada kemungkinan anak didiknya juga berakhlak buruk. Sikap keteladanan menjadi penting dalam pendidikan akhlak.Keteladanan akan menjadi metode ampuh dalam membina akhlak anak. Mengenai hebatnya keteladanan Allah mengutus Rasul untuk menjadi teladan

13Abdurrahman An-Nahlawi, Ushulut Tarbiyah..., 61.

14Zuhairini, dkk, Metodik Khusus Pendidikan Agama, (Surabaya: Usaha Nasional, 1983), 104

15Muhammad bin Ibrahim al- Hamd. Maal Muallimin, (terj), (Jakarta: Darul Haq, 2002), 74 
yang paling baik, Muhammad adalah teladan tertinggi sebagai panutan dalam rangka pembinaan akhlak mulia, seperti dalam firman Allah swt.

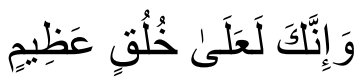

Artinya: "Dan sesungguhnya engkau (Muhammad) benarbenar berbudi pekerti yang agung”. (Q.S. Al-Qalam, 66:4).

4. Metode Adat kebiasaan, Imam Ghazali menyatakan anak adalah amanah bagi kedua orang tuanya. Hatinya yang suci adalah permata yang sangat mahal harganya. Jika dibiasakan pada kejahatan dan dibiarkan seperti dibiarkannya binatang, ia kan celaka dan binasa. Sedangkan memeliharanya adalah dengan upaya pendidikan dan mengajari akhlak yang baik.

5. Perhatian, Islam dengan keuniversalan prinsip dan peraturannya yang abadi, memerintah para orang tua dan pendidik untuk memperhatikan dan senantiasa mengikuti serta mengawasi anak-anaknya dalam segala segi kehidupan dan pendidikan yang universal. Setiap anak membutuhkan perhatian dari orang disekitarnya tanpa terkecuali orang tua. Hal ini terbukti karena anak akan mencari cara agar dia mendapatkan perhatian tersebut. Maksud metode perhatian ini tidak lain adalah mencurahkan, memperhatikan dan senantiasa mengikuti perkembangan anak dalam pembinaan akidah dan moral, persiapan spiritual dan sosial, serta salalu bertanya tentang situasi pendidikan jasmani daya hasil ilmiahnya.

6. Hukuman, yang dipakai Islam dalam memberikan hukuman kepada anak dengan cara lemah lembut dan kasih sayang yang merupakan dasar pembenahan anak, menjaga tabiat anak yang salah dalam menggunakan hukuman dan dalam upaya pembenahan hendaknya dilakukan secara bertahap dari yang paling ringan hingga yang paling keras.

\section{Kurikulum Pendidikan Pesantren}

Istilah kurikulum berasal dari bahasa Latin yaitu curriculum yang memiliki pengertian running cource dalam Bahasa Inggris curier yang berarti to run. Istilah ini kemudian diadopsi dalam dunia pendidikan menjadi sejumlah mata pelajaran (course) yang 
harus ditempuh untuk mencapai suatu gelar penghargaan dalam dunia pendidikan yang dikenal sebagai ijazah.16

Sedangkan menurut H.M. Arifin definisi kurikulum diperluas tidak sebatas pada mata pelajaran tetapi seluruh program sekolah yang mempengaruhi proses belajar mengajar baik langsung dalam sekolah maupun luar sekolah. Demikian pula menurut Nur Uhbiyati menjelaskan bahwa kurikulum memiliki 3 pengertian, yaitu:17 1) kurikulum adalah program pendidikan yang terdiri beberapa mata pelajaran yang diambil anak didik pada suatu jenjang sekolah; 2) kurikulum adalah semua pengalaman yang diperoleh anak selama belajar di sekolah; 3) kurikulum adalah rencana belajar siswa guna mencapai tujuan yang telah di tetapkan. Sehingga kurikulum dapat meliputi kegiatan-kegiatan intra kurikuler, kokurikuler dan ekstra kurikuler serta aktifitas para santri maupun aktifitas para kyai sebagai pendidik atau guru.

Sejalan dengan konsep kurikulum para tokoh pendidikan di atas maka kurikulum di Dayah bersifat lokal. Artinya tidak ada ketentuan dari pusat terkait bentuk kurikulum tertentu yang harus dijadikan rujukan. Sebagaimana pengakuan para ulama dayah dalam buku Apresiasi Dayah sebagai Lembaga Pendidikan Islam di Aceh, menyatakan bahwa tidak ada suatu kurikulum yang menjadi ketentuan pusat yang menjadi rujukan dan tolak ukur semua lembaga pendidikan dayah di Aceh. Kurikulum yang dikembangkan di dayah hanya tergantung kepada keinginan dan kemampuan para pemimpinnya saja. Kendati demikian, secara umum terdapat persamaan di semua dayah tentang mata pelajaran pokok yang diajarkan kepada para santrinya. Misalnya pengetahuan hukum Islam (Ilmu Fiqih), tata bahasa (Ilmu Nahu dan Ilmu Saraf), Tauhid dan Tafsirdan Ilmu Akhlak dan Tasawuf.18

16 S. Nasution, Asas-Asa Kurikulum, (Bandung : Transito, 1978), 5

${ }_{17}$ Nur Uhbiyati, Manajemen Pelaksanaan Kurikulum Pondok Pesantren Salaf Al-Fadlu Kaliwungu, Kendal, Jurnal Walisongo Vol. XI (2012), 269

${ }_{18 B u k u}$ 'Apresiasi Dayah Sebagai Lembaga Pendidikan Islam di Aceh' merupakan buku yang berisi kumpulan berbagai fatwa ulama dayah, berbagai laporan tentang dayah di Aceh serta hasil keputusan rapat kerja ulama dayah di Aceh yang tergabung dalam Persatuan Dayah Inshafuddin seluruh Aceh, sejak awal pembentukan organisasi ini hingga saat ini tahun 2010). Dicetak 
Kitab-kitab yang diajarkan dalam pelajaran Akhlak di dayah adalah sebagai meliputi kitab Pelajaran Akhlak Jawi, kitab Akhlak lil Banin, kitab Taisir Akhlak, dan kitab Ta'lim Muta'alim. Semua kitab atau mata pelajaran diatas diajarkan berdasarkan kemampuan guru (teungku beut) di sebuah Dayah. Kurikulum merupakan salah satunya, dimana mata pelajaran yang diajarkan di dayah tidak berubah dari masa ke masa, umumnya materi pelajaran lebih dominan di bidang fiqih, akhlak dan tauhid. Sementara untuk bidang lainnya, walaupun ada yang masih tergolong minim. Selain itu ilmu pendukung seperti sains tidak tersentuh hingga kini, sehingga tak jarang banyak orang menyepelekan alumni Dayah karena wawasan yang sempit dan tidak mengikuti perkembangan zaman.

Berdasarkan hasil wawancara dengan guruDayah Ummul Ayman, bahwa;

Pelaksanaan proses belajar mengajar di dayah mengacu pada kurikulum yang tetap, dan pada umumnya kurikulum dayah yang ada di Aceh sama, yaitu mengikuti mazhab Imam syafi'ai. Namun kurikulum tersebut belum tertulis dengan lengkap dan belum sama seperti pada lembaga pendidikan formal yang memiliki standar kompetisi dan kompetisi dasarnya, karena proses pembelajaran di Dayah akan dianggap tuntas bila santrinya benar-benar menguasai isi kitab tersebut. 19

Khusus untuk pembelajaran Kitab ta'lim Mutha'alim, sangat diintensifkan dengan menitikberatkan pengamalan pada penghayatan dari isi kitab tersebut. Menurut Tgk Abdullah, beliau menjelaskan bahwa

Kitab Ta'lim Muta'alim yang disusun dan dikarang oleh Syekh Az-Zarnuji, merupaka kitab dan acuan sekaligus bimbingan bagi seorang penuntut ilmu agar mendapatkan ilmu yang bermanfaat bagi dirinya dan masyarakat pada umumnya. Dalam kitab ini terdapat banyak sekali petunjukpetunjuk bagi seorang penuntut ilmu, seperti halnya memilih

dan diperbanyak oleh Pengurus Besar Persatuan Dayah Inshafuddin, Banda Aceh, 2010.

${ }_{19}$ Wawancara dengan Tgk. Januddin, salah seorang Guru Pesantren Ummul Ayman, pada tanggal 13 Februari 2017. 
guru dan teman yang akan dijadikan seorang guru dan teman untuk berdiskusi dan mencari solusi dalam permasalahan yang ada dalam masyarakat, cara memuliakan ilmu dan shahibul ilmi dan masih banyak hal-hal yang berhubungan dengan hak dan kewajiban penuntut ilmu, maka dari itu. Kami selaku pengajar di dayah lebih memilih kitab ini sebagai panduan dalam mengajar dan membina akhlak santri.20

Berdasarkan kurikulum yang telah disusun di Dayah tersebut, pembelajaran yang wajib dipelajari di kelas selama 2 jam sehari, yaitu pada jadwal belajar pagi dan malam hari. Karena di dayah tersebut jadwal belajar ilmu agama terbagi dalam dua shif, yaitu pagi dari jam 08.00 wib sampai jam 10.30 wib. dan malam hari dari jam 20.00 wib sampai jam 23.00 wib. sedangkan sore hari, santri belajar materi umum di sekolah menurut jenjang pendidikannya masing-masing yang terdiri dari Sekolah Menengah Pertama (SMP) dan Sekolah Menengan Atas (SMA) yang berada dalam satu atap komplek dayah.

Setiap teungku yang menjadi guru di kelas ketika proses pembelajaran, tidak hanya mengasuh pelajaran akhlak, namun juga mencakup pelajaran fiqih, nahwu, tauhid dan lain sebagainya. Setiap santri wajib memiliki kitab pelajarannya masing-masing. Khusus untuk pelajaran akhlak menggunakan kitab yang telah tersebut di atas sesuai dengan tingkatan jenjang santri, namun sejauh pantaun peneliti, guru tidak menggunakan Rencana Pelaksanaan Pembelajaran (RPP) sebagai pedoman untuk mengajar. Rencana Pelakanaan Pembelajaran disesuaikan dengan urutan materi yang ada didalam kitab.

Disisi lain, berdasarkan hasil wawancara dengan guru Dayah Jamiah Al-Aziziyah Samalanga dan beliau juga merupakan Kepala Sekolah SMP S Jamiah Al-Aziziyah Samalanga, menyatakan bahwa sebaik apapun sistem dan kurikulum pendidikan agama maupun akhlak yang disusun oleh pemerintah atau swasta lainnya, bila pendidikannya tidak memberlakukan pendidikan boardingschool maka akan sia-sia juga. Karena bila materi pelajaran yang sudah dipelajari oleh siswa tidak

20Wawancara dengan Tgk. Abdullah, salah seorang Guru Pesantren Jami’ah Al-Aziziyyah, pada tanggal 20 Februari 2017 
direalisasikan secara langsung dan diawasi langsung oleh gurunya juga akan sia-sia.

Berdasarkan hasil penelitian yang dilakukan oleh Nurochim dalam jurnal Al-Tahrir bahwa Karakteristik utama pendidikan pesantren terlihat dari aspek ibadah, aspek muamalah, aspek pendidikan, kepemimpinan, dan kelembagaan. Aspek ibadah seperti salat berjamaah, salat tahajud, berjanzi, istighosah, manakib, tahlil, dan sebagainya. Aspek muamalah misalnya ukhuwah, berbusana muslim, disiplin, keamanan yang terjamin, kontrol pergaulan, pengaturan jam makan, tidur, piket, dan sanksi. Aspek Pendidikan, contohnya orientasi kebahagian dunia dan akhirat, ilmu agama, akhlaqul karimah, bebasis kitab yang diajarkan/kitab kuning, pendidikan keterampilan, menghormati yang lebih tua. Kepemimpinan misalnya keteladanan kyai, ketaatan/kepatuhan kepada kyai, badal/wakil, penjenjangan santri, jejaringan kyai/ulama. Kelembagaan seperti kemandirian pengelolaan dan sumber daya ekonomi, jaringan kerjasama dengan berbagai instansi, forum-forum santri dan dukungan masyarakat. Lembaga pesantren merupakan bagian dari pendidikan keagamaan Islam yang mempersiapkan peserta didik untuk dapat menjalankan peranan yang menuntut penguasaan pengetahuan tentang ajaran Agama Islam dan atau menjadi ahli ilmu Agama Islam dan mengamalkan ajaran agama Islam.21

Oleh karena demikian berdasarkan analisis peneliti, persoalan mengapa pendidikan pesantren/dayah dianggap lebih berhasil dalam segi pembinaan akhlak, jawabannya karena pendidikan pesantren berlangsung selama 24 jam dibawah binaan teungku-teungku Dayah.

\section{Media Pembelajaran}

Media pembelajaran akan memberikan pengaruh terhadap peserta didik, yaitu peserta didik akan memiliki pemahaman yang bagus tentang materi yang didapatkan, juga akan memiliki moral atau akhlak yang tinggi, sehingga besar kemungkinan

21 Nurochim, Sekolah Berbasis Pesantren Sebagai Salah Satu Model Pendidikan Islam Dalam Konsepsi Perubahan Sosial, Jurnal Al-Tahrir (2016), 84 
dengan memperhatikan alat/media pembelajaran itu, tujuan pembelajaran akan tercapai secara efektif dan efisien.22

Ada kata kunci baru yang muncul dari pengertian menurut Rustyah, yaitu media sebagai alat bantu proses penyampaian pesan. Alat bantu mempunyai pengertian yang lebih luas dari sekedar alat berbentuk fisik. Hal ini lebih dipertegas oleh Basyiruddin yang menyebutkan, "Pengertian media secara lebih luas dapat diartikan manusia, benda atau peristiwa yang membuat kondisi siswa memungkinkan memperoleh pengetahuan, keterampilan atau sikap".23

Setiap pembelajaran tentunya didukung oleh ketersediannya media pembelajaran yang memadai. Begitu juga halnya dengan pembelajaran akhlak di Dayah Modern Ummul Ayman dan Dayah Jami'ah Al-Aziziyah Samalanga Kabupaten Bireuen. Media pembelajaran yang tersedia di Dayah terbagi ke dalam dua bentuk media, yaitu media audio dan media nonaudio. Guru dayah tidak banyak menggunakan media audio, hal ini berdasarkan wawancara penulis dengan salah seorang guru Dayah, beliau menjelaskan bahwa"Pembelajaran di dayah hanya menggunakan media papan tulis, kitab, spidol dan alat tulis lainnya sebagai media pembelajaran bagi santri. Hal ini mengingat akan keterbatasannya perangkat media yang dimiliki oleh lembaga pendidikan dayah".24

Hasil observasi penulis, di lembaga pendidikan dayah sudah memiliki media audio yang bisa digunakan dalam pembelajaran. Hal ini karena mengingat tradisi proses pembelajaran di dayah berlangsung secara tatap muka dengan duduk bersila, guru membaca kitab dengan melanjutkan materi yang telah dipelajari sebelumnya, sedangkan santri hanya mendengarkan dan mendiskusikan materi yang belum dipahaminya.

Disisi lain, berbeda dengan halnya pembinaan akhlak di Dayah Jamia'h Al-Aziziyah, penggunaan media audio rutin digunakan oleh guru dayah dengan memutarkan film-film yang mengisahkan keteladanan para sahabat-sahabat Rasul dan

${ }_{22}$ Basyiruddin Usman.Media Pendidikan. (Jakarta; Ciputat Press. Buchari Alma, 2002), 191.

23Usman.Media..., 127

24Wawancara dengan Tgk. Marzuki, salah seorang Guru Pesantren Ummul Ayman, pada tanggal 22 Februari 2017 
keberhasilan-keberhasilan ulama dahulu dalam menuntut ilmu, hal ini dilakukan untuk mencapai tujuan pendidikan akhlak bagi santri dayah.

Kemampuan guru Dayah Jamiah Al-Aziziyah Samalanga dalam menggunakan media audio dilatarbelakangi oleh keilmuan teungku dayah yang sudah berada pada level strata dua (S2) dan bahkan ada yang sudah strata tiga (S3). Maka sangat banyak ideide pengembangan akhlak santri yang dilakukan oleh santri dayah.

Selain media audio tersebut, teungku-teungku dayah juga menjadikan sarana madding sebagai media pembelajaran. Menurut hasil wawancara dengan Teungku Saiful Bahri, beliau menyatakan bahwa "Madding menjadi salah satu media pembinaan akhlak santri, di madding kami menulis berbagai artikel yang bernuansa sufisme, menulis kisah-kisah keteladanan ulama-ulama terdahulu, sehingga santri yang membacanya terispirasi dengan tulisan tersebut. Selain tulisan, di madding juga memuat karikatur-karikatur islami yang bernilai etika dan estetika yang tinggi.25

Media lain yang berhasil peneliti rangkumkan di dayah adalah adanya penulisan kata-kata bijak yang ditempelkan di sudut-sudut bangunan dayah. Hasil observasi di Dayah Ummul Ayman, bahwa tertulis di sudut asrama putra tentang adab murid kepada gurunya. yaitu : 1) tidak berjalan di depan guru; 2) tidak menduduki tempat yang di duduki seorang guru; 3) tidak mendahului bicara di hadapan guru kecuali dengan izinnya; 4) tidak bertanya dengan pertanyaan yang membosankan guru; 5) tidak mengganggu istirahat guru; dan 6) tidak menyakiti hati guru.

Berbeda lagi dengan di Dayah Jamiah Al-Aziziyyah, guru dayah lebih menekankan prilaku santri kearah yang lebih terpuji, dengan menjauhi 7 dosa besar santri, berupa: 1) tidak boleh mencuri; 2) tidak boleh menggauli teman; 3) tidak boleh keluar komplek dayah; 4) tidak boleh memasak di luar dayah; 5) tidak boleh melawan guru; 6) tidak boleh merokok; dan 7) tidak boleh merusak fasilitas sekolah/dayah.

${ }_{25}$ Wawancara dengan Tgk. Saiful Bahri, salah seorang Guru Pesantren Jami’ah Al-Aziziyyah, pada tanggal, 20 Februari 2017 
Larangan tersebut di atas ditempelkan di sudut-sudut dayah, sehingga santri terbiasa melihat aturan tersebut. Langkah ini sangat efektif dalam melatih kebiasaan santri untuk memperbaiki akhlaknya masing-masing.Selain memanfaatkan sarana madding sebagai media pembelajaran akhlak, di Dayah Jamiah AlAziziyah memanfaat soudsystem yang dipasang di setiap asrama santri, yang berguna untuk memberi informasi terbaru bagi setiap santri. Hal ini berdasarkan hasil wawancara peneliti dengan Teungku Riandi, beliau menjelaskan, bahwa;

"Pada sudut-sudut asrama santri telah kita pasang sound system yang berguna untuk media informasi seputaran aturan dayah, selain itu juga pada soundsystem tersebut kami putarkan tausiah-tausiah penyejuk hati, cara-cara membersihkan hati dari penyakit hati, ini sangat berguna bagi santri yang lagi menuntut ilmu, karena bila hati seseorang hitam, maka ilmu agama akan susah masuk ke dalam hati manusia".26

Hasil observasi peneliti, sangat banyak kelebihan lain dari pemasangan soundsystem di asrama santri, antara lain adanya informasi yang disampaikan oleh piket harian di posko utama secara langsung diterima oleh santri bila ada wali santri yang berkunjung ke Dayah.

\section{Metode Pembelajaran}

Metode merupakan salah satu komponen dalam sistem pembelajaran dan menempati posisi yang tidak kalah penting dari komponen-komponen yang lain.hal ini dikarenakan penggunaan metode yang tepat akan sangat mudah untuk mencapai tujuan pembelajaran.

Berbicara tentang pembinaan akhlak di dunia pendidikan, tidak akan terlepas dari 2 (dua) lembaga pendidikan di Indonesia yaitu lembaga pendidikan formal dan non formal. Lembaga pendidikan formal terdiri dari SD, SMP, SMA sampai dengan Perguruan Tinggi. Sedangkan lembaga pendidikan non formal yaitu lembaga pendidikan pesantren atau dayah dalam sebutan masyarakat Aceh.

26 Wawancara denganTgk. Riandi, salah seorang Guru Pesantren Jami'ah Al-Aziziyyah, pada tanggal 23 Februari 2017 
Sampai saat ini khususnya di Aceh, Dayah telah diakui atas keberhasilannya dalam membina akhlak santri. Hal ini sangat berhubungan dengan penggunaan metode pembinaan akhlak yang diterapkan di lembaga pendidikan dayah. Adapun metode pembinaan akhlak bagi santri di dayah adalah sebagai berikut:

1. Pelurusan Motivasi (Niat Belajar). Menurut Teungku Januddin yang merupakan salah seorang guru di Dayah Ummul Ayman, seraya mengutip isi kitab Ta'limMutha'alim menjelaskan bahwa:

"Niat adalah azas segala perbuatan, maka dari itu adalah wajib berniat dalam belajar. Konsep niat dalam belajar ini mengacu kepada hadis Nabi saw yang artinya "Hanyasanya semua pekerjaan itu harus mempunya niat, dan hanyasanya setiap pekerjaan itu apa yang ia niatkan".(HR. Bukhari) Dengan demikan amal yang berbentuk duniawi seperti makan, minum dan tidur bisa jadi amal ukhrawi dengan niat yang baik. Dan sebaliknya amal yang berbentuk ukhrawi seperti shalat, membaca zikir jadi amal duniawi dengan niat yang jelek seperti riya".27

Dalam hal belajar hendaklah berniat untuk: 1) mencari ridha Allah 'Azza wa Jalla; 2) memperoleh kebahagiaan akhirat; 3) berusaha memerangi kebodohan pada diri sendiri dan kaum yang bodoh; 4) mengembangkan dan melestarikan Islam; dan 5) mensyukuri nikmat akal dan badan yang sehat. Motivasi agama dan kehidupan akhirat menjadi faktor pendukung terciptanya suasanasakral dalam proses belajar dan mengajar. Teungku dalam mengajar dan santri ketika belajar meyakini bahwa sedang menjalankan ibadah. Keyakinan tersebut membawa pengaruhkepada teungku dan santri serius dan konsentrasi dalam proses belajar-mengajar. Belajardi dayah dilakukan secara komprehensif antara pemahaman keilmuan dan praktik ibadah.Belajar di dayah tidak bersifat transaksional. Artinya, mereka tidak melakukan proses transaksidalam pengajaran, sehingga tidak ada penentuan standar bayaran atau gaji setelah

27Wawancara dengan Tgk. Januddin, salah seorangGuru Pesantren Ummul Ayman, pada tanggal 13 Februari 2017 
selesaimengajar, hubungan antara tenaga pengajar dengan santri terjalin dengan baik dalam suasanakebersamaan dan ukhuwah al-Islâmiyah. Teungku memperhatikan kehidupan santri di dayahdan memberikan perhatian penuh kepada santri. Pimpinan dayah dan tenaga pengajardi dayah menjadi teladan dalam kehidupan santri. Di samping itu juga rajin membacabahkan menghafal kitab kuning yang menjadi pegangan dalam pengajiannya.28

2. Nasihat selalu menyertai santri selama mereka berada di lingkungan dayah. Hal ini dikarenakan nasihat yang diberikan oleh orang-orang yang bertanggung jawab terhadap pembinaan akhlak di dalam dayah. Melalui nasihatnasihat yang baik, santri mendapatkan pencerahan dan solusi dari hal-hal yang dihadapi dalam kesehariannya.

Menurut wawancara peneliti dengan Teungku Muntasir yang merupakan Pimpinan Dayah Jami'ah Al-Aziziyyah Samalanga menyatakan bahwa "Setiap malam selesai shalat magrib, guru dayah secara bergilir selalu menyampaikan tausiah selama 10 menit, materi yang disampaikan berkaitan dengan akhlak dan tasawuf. Hal ini terus kami lakukan secara rutin sejak lembaga ini kami dirikan, dengan harapan dari berbagai materi tausiah yang didengarkan oleh santri ada poin-poin inti yang terlintas di hati santri sehingga mampu diaplikasikan dalam kehidupan di dayah".29

3. Keteladanan, merupakan salah satu metode yang paling efektif dalam pembinaan akhlak di Dayah, dikarenakan melalui keteladanan-lah santri mendapat gambaran nyata bagaimana seharusnya bersikap. Keteladanan yang mereka lihat langsung dari para guru,khususnya keteladanan terkait ketaatan dalam pelaksanaan kedisiplinan.

Berdasarkan hasil wawancara dengan Teungku Yusfriadi, menyatakan bahwa "Seorang pengajar (guru) wajib memiliki sikap keteladanan yang sangat terpuji, sikap dan tingkah laku guru akan menjadi pedoman bagi muridnya. Diantara keteladanan yang wajib diperankan oleh guru adalah guru

28 Silahuddin.Budaya Akademik Dalam Sistem Pendidikan Dayah Salafiyah Di Aceh, Jurnal MIQOT Vol. XL (2016), 363.

${ }_{29}$ Wawancara denganTgk. Muntasir, Pimpinan Pesantren Jamiah AlAziziyah, pada tanggal 20 Februari 2017 
dilarang merokok di komplek dayah, baik di hadapan santri maupun di belakang santri"..30

Guru berhasil menjadi teladan sepenuhnya dalam berbagai kegiatan hidup yang dilalui oleh santri di lingkungan dayah. Misalnya, dalam kegiatan spiritual shalat, guru bertindak sebagai imam dan begitu juga pada doa-doa lainnya. Selain itu pengasuh yang bertempat tinggal di lokasi dayah menjadikan kehidupan dan bahkan juga seluruh keluarganya sebagai contoh hidup yang sebenarnya. Para aneuk beut (santri) tidak saja belajar dari buku atau kitab yang dipelajari, melainkan juga dari kehidupan nyata para pengasuh dayah. Sehingga aneukbeut memahami bahwa para guru pengasuhnya tidak saja mengajari melainkan lebih dari itu berdoa dan memohon kepada Allah swt. atas keberhasilan para santrinya dalam menuntut ilmu di Dayah

Hasil studi dokumentasi peneliti terhadap Standar Operasional Pelayanan (SOP) guruDayah Jamiah AlAziziyyah diantaranya adalah: 1) guru tidak boleh memakai celana jeans; 2) guru tidak boleh mengendarai sepeda motor di komplek dayah; dan 3) guru wajib melaksanakan shalat berjamaah bersama santri.

4. Praktek dan Pembiasaan dalam Ibadah. Metode pembinaan akhlak tidak hanya diberikan dengan nasihat dan keteladanan tentang bagaimana berakhlak yang baik, tapi santri juga dituntut mempraktekkan hal-hal tersebut. Setelah dipraktekkan, santri juga dibisakan untuk menerapkannya dalam kehidupannya.Menurut pimpinan dayah, "Kegiatan santri di dayah telah disusun dengan sedemikian rupa untuk menjadi amaliah sehari-hari, diantaranya adalah santri wajib melaksanakan shalat sunat rawatib qabliah dan ba'diah, melaksanakan shalat sunat dhuha setiap pagi, wirid yasin setiap sore jam 18.00, dan lain sebagainya".31

Berdasarkan observasi penulis di Dayah Ummul Ayman, selesai jadwal belajar pagi jam 10.30 wib semua santri

30Wawancara denganTgk. Yusfriadi, salah seorang Guru Pesantren Jamiah Al-Aziziyah, pada tanggal 20 Februari 2017

31 Wawancara denganTgk. Marzuki, salah seorang Guru Dayah Ummul Ayman, pada tanggal 15 Februari 2017 
diarahkan ke mushalla dayah untuk melaksanakan shalat dhuha dibawah bimbingan seksi ibadah. Setelah shalat dhuha jam 11.00 wib santri wajib istirahat. Hal ini dilakukan sesuai dengan kebiasaan yang dilakukan oleh Rasulullah yaitu beristirahat pada waktu kailulah (waktu satu jam sebelum tiba waktu shalat dhuhur).Demikian juga di Dayah Jami'ah Al-Aziziyyah yang menjadirutinitas setiap sore sebelum shalat magrib dengan melaksanakan wirid Yasin setiap jam $18.00 \mathrm{Wib}$ di dalam mushalla dayah.

Kepedulian pendidik/teungku selain dalam proses belajar mengajar dan ibadah, juga mengajarkan cara menyampaikan ilmu kepada masyarakat. Sebab santri ini adalah cikal bakal penerus dan ujung tombak yang akan membantu masyarakat dalam menyelesaikan hukum-hukum yang berkaitan dengan pelaksanaan ibadah dan munakahat.

5. Bimbingan dan Pendampingan, merupakan metode yang sangat efektif diterapkan di lingkungan dayah. Metode ini dilaksanakan dengan tujuan untuk mendekatkan diri santri dengan guru pengasuhnya, menyelesaikan berbagai kesulitan proses belajar santri dan juga menjadi mediator dalam menangani masalah pribadi santri.

Berdasarkan hasil wawancara penulis dengan Teungku Muhibbuddin, beliau menyatakan bahwa;

"Disetiap kamar (bilik) wajib didampingi oleh salah seorang santri senior atau guru pembantu yang disebut dengan nama mudabbir. Fungsi mudabbir yang ditempatkan di setiap kamar adalah memfasilitasi berbagai permasalahan yang dihadapi oleh santri. Maka di dayah ini orang yang sangat memahami psikologi santri adalah mudabbirnya, jadi setiap wali yang akan mengetahui perkembangan keilmuan dan sikap anaknya, wali cukup hanya bertemu dengan mudabbir kamarnya masing-masing tanpa perlu menemui pimpinan dayah atau guru lainnya".32

Menurut hemat peneliti, metode ini adalah metode yang sangat efektif dilaksanakan di lembaga pendidikan dayah dan

32Wawancara denganTeungku Muhibbuddin, salah seorang Guru Pesantren Jamiah Al-Aziziyah, pada tanggal 20 Februari 2017 
bisa menjadi model pendampingan akhlak bagi lembaga pendidikan lainnya.

6. Koordinasi Dayah dengan Wali. Dayah Jami'ah Al-Aziziyyah tergolong masih sangat baru, yaitu didirikan pada tahun 2012. Namun, tekat dan cita-cita Dayah Jami'ah Al-Aziziyyah untuk membimbing santrinya ke arah yang berakhlaqul karimah perlu mendapat apresiasi yang tinggi. Berawal dari saat pendaftaran santri baru, setiap wali santri wajib menandatangani fakta integritas sebagai bentuk pertanggungjawaban terhadap keberlangsungan pendidikan anaknya di Dayah Jami'ah Al-Aziziyyah.

Salah satu tanggung jawab yang dibebankan kepada wali adalah dengan menjeput dan mengantarkan langsung anaknya disaat mereka liburan. Selain itu, berdasarkan wawancara penulis dengan Teungku Riandi, beliau menyatakan bahwa:

"Wali wajib memberikan informasi tentang keberadaan anaknya. Sebagai contoh adalah disaat wali kelas mendapatkan laporan dari mudabbir bahwa salah seorang santri tidak berada di kamar, dan juga tidak berada di kelas belajar, maka wali kelas langsung menelpon walinya untuk menanyakan posisi keberadaan anaknya yang sedang tidak berada di dayah. Jadi seorang wali yang mendapat kabar bahwa anaknya tidak berada di dayah, mereka langsung mencari tau keberadaan anaknya, ada yang mereka temukan lalu diantarkan lagi ke dayah, kemudian wali santri meminta maaf kepada wali kelas dan mudabbir atas kelakuan anaknya".33

Metode tersebut di atas sangat jarang diterapkan di lembaga pendidikan dayah lainnya, lebih lagi pada lembaga pendidikan umum di luar dayah. Menurut hemat peneliti, wali murid di lembaga pendidikan lainnya lebih menitikberatkan tanggung jawab sukses pendidikan anaknya kepada guru atau lembaga pendidikan tersebut. Terlebih lagi sangat disayangkan bila ada wali murid yang tidak pernah menanyakan perkembangan anaknya kepada gurunya di

33Wawancara denganTgk. Riandi, salah seorang Guru Pesantren Jami'ah Al-Aziziyyah, pada tanggal 23 Februari 2017 
sekolah. Padahal akan sangat mustahil suksesnya pendidikan anak, tanpa peran orang tua.

7. Koordinasi dengan Stakeholder. Metode pembinaan akhlak di Dayah Jami'ah Al-Aziziyyah tidak hanya sebatas koordinasi dengan wali santri, namun Dayah Jami'ah Al-Aziziyyah juga menjalin koordinasi dengan stakeholder di lingkungan dayah.

Hasil wawancara peneliti dengan salah seorang guru dayah Jami'ah Al-Aziziyyah, menyatakan bahwa:

"Salah satu struktur organisasi Dayah Jami'ah Al-Aziziyyah adalah adanya bidang humas. Humas di dayah berfungsi membangun kerja sama dengan masyarakat khususnya masyarakat di sekitar dayah. Salah satu bentuk kerja sama yang telah dilakukan adalah dengan memfasilitasi HT kepada setiap pemilik warung kopi di sekeliling dayah.Hal ini bertujuan untuk memantau pergerakan santri yang keluar dari komplek dayah tanpa izin dari mudabbir. Sehingga bila ada santri yang keluar dari komplek dayah dan duduk di warung kopi, maka pemilik warung kopi langsung memberitahukan tentang keberadaan salah seorang santri ke guru dayah atau mudabbir asramanya. Sehingga guru bersama mudabbir langsung menjemput santri tersebut untuk dibawa kembali ke dayah".34

Metode membangun koordinasi dengan berbagai stakeholder dayah telah dapat meminimalisir persentase santri yang bolos dari jadwal belajar. Metode ini belum pernah peneliti temui di lembaga pendidikan lainnya di luar dayah tersebut..

8. Reward dan Funishment. Pembinaan akhlak di dayah diantaranya juga melalui reward dan funishment. Metode rewarddan funishment dilaksanakan dengan berpedoman kepada hasil penilaian akhir dari mudabbir dan wali kelas.

Menurut penuturan salah seorang guru dayah, beliau menyatakan bahwa:

"Setiap santri pasti berbeda sikap antara satu santri dengan santri lainnya, maka kami selaku dewan guru membuat aturan untuk dilaksanakan dengan baik, namun bila ada santri yang melanggarnya maka akan dikenakan sanksi

${ }_{34}$ Wawancara dengan Teungku Mursal, salah seorang Guru Pesantren Jamiah Al-Aziziyah, pada tanggal22 Februari 2017 
berdasarkan tingkat kesalahan yang dilanggar. Dimana tingkat pertama bila santri melakukan kesalahan akan dipanggil dengan menanda tangani surat perjanjian sebagai peringatan pertama, bahwa tidak akan mengulangi lagi kesalahan. Bila ada santri yang mengulangi kesalahannya akan dipanggil orang tua. Namun bila juga ada santri yang mengulangi lagi kesalahan ketiga kalinya, maka guru akan memanggil orang tuanya untuk diserahkan kembali santri tersebut kepada orang tuanya. 35

Namun sebaliknya, reward juga diberikan dan menjadi impian setiap santri untuk menjadi santri terfavorit. Disetiap memasuki bulan Muharram tahun Hijriah, dayah selalu mengadakan pemilihan santri teladan, penetapan santri teladan harus berdasarkan kriteria-kriteria yang telah ditetapkan. Santri yang terpilih sebagai santri teladan akan diberikan penghargaan dan hadiah.

9. Out put pembinaan akhlak. Keberhasilan pembinaan akhlak di dayah sudah mendapat pengakuan dari berbagai komponen masyarakat, khususnya wali santri. Perubahan prilaku santri ke arah yang lebih baik secara langsung dapat direalisasikan pada saat santri berkumpul bersama keluarganya. Hasil wawancara peneliti dengan salah seorang wali santri menyatakan bahwa "Sejak saya antarkan anak saya ke dayah, Alhamdulillah saya sudah merasakan langsung perubahan sikap pada diri anak saya, terutama yang berkaitan dengan ibadah, sebagai contoh dulu sebelum anak saya belajar di dayah sangat susah bangun shalat shubuh, namun beberapa bulan setelah anak saya belajar di dayah, pada saat liburan Bulan Ramadhan saya merasa bangga anak saya rajin shalat wajib dan rajin melaksanakan ibadah shalat tarawih".36

Selain itu, banyak sekali keberhasilan aneuk beut atau santri yang telah terjun ke tengah masyarakat di berbagai profesi dan dapat mendorong pengembangan masyarakat sesuai

35Wawancara dengan Teungku Abdullah, salah seorang Guru Pesantren Jamiah Al-Aziziyah, pada tanggal 22 Februari 2017

36Wawancara dengan Muhammad, salah seorang Wali Santri, pada tanggal 25 Februari 2017 
dengan nilai-nilai kemasyarakatan yang berguna. Keberhasilan aneuk beut dari pemberdayaan yang dilakukan oleh dayah juga dapat dilihat dari para alumninya yang telah berhasil dalam bidang pekerjaannya masing-masing. Ada yang berkerja sebagai penulis, peneliti, guru, kepala sekolah, bekerja di media massa, LSM, instansi pemerintah dan ada juga yang telah berhasil mendirikan serta memimpin dayahdayah besar di Aceh dan sekitarnya.

\section{Pembinaan Akhlak Santri pada Siswa Sekolah}

Proses pembinaan akhlak di suatu komunitas masyarakat dengan komunitas yang lain tentu memiliki kriteria sendiri. Begitu juga halnya dengan pembinaan akhlak di lembaga pendidikan. Di Indonesia terdapat 2 lembaga pendidikan yaitu pendidikan formal dan pendidikan non formal. Lembaga pendidikan formal adalah lembaga pendidikan yang dikelola oleh pemerintah dari jenjang PAUD sampai jenjang perguruan tinggi. Sedangkan lembaga pendidikan non formal adalah lembaga pendidikan yang dikelola oleh masyarakat yang meliputi lembaga pendidikan pesantren atau dayah. Dari hasil penelitian yang telah penulis lakukan di 2 lembaga pendidikan tentang pembinaan akhlak, terdapat perbedaan yang mendasar tentang pembinaan akhlak. Adapun perbedaannya dapat dilihat pada tabel di bawah ini;

\begin{tabular}{clll}
\hline NO & Pembinaan Akhlak Santri & Pembinaan Akhlak Siswa \\
\hline Kurikulum Pembinaan Akhlak & \\
\hline 1 & $\begin{array}{l}\text { Pelajaran akhlak (kitab Taisir } \\
\text { Akhlaq) }\end{array}$ & $\begin{array}{l}\text { Pelajaran Agama Islam } \\
\text { (Buku Paket Agama Islam) }\end{array}$ \\
\hline 2 & Pelajaran Tasawuf (kitab & Pelajaran Aqidah (Buku \\
& Ta'limul Muta'allim, kitab & Paket Aqidah Akhlak) \\
& Daqaikul Akhbar, kitab & \\
& Muraqi Ubudiyah, kitab \\
& Sirajut Thalibin) \\
\hline 3 & Istighfar setiap selesai shalat \\
\hline 4 & Wirid Yasin Setiap Magrib \\
\hline Media Pembelajaran \\
\hline 1 & $\begin{array}{l}\text { Kitab-kitab klasik karangan } \\
\text { ulama }\end{array}$ \\
\hline
\end{tabular}




\begin{tabular}{clll}
\hline 2 & Madding & Buku Paket Aqidah Akhlak \\
\hline 3 & $\begin{array}{l}\text { Pemutaran film-film islami } \\
\text { audio visual) }\end{array}$ & \\
\hline 4 & Buku-buku islami & \\
\hline Metode Pembinaan Akhlak & $\begin{array}{l}\text { Ceramah pada Upacara Hari } \\
\text { Belajar) }\end{array}$ & $\begin{array}{l}\text { Senin } \\
\text { Ceramah Setiap Hari Jumat } \\
\text { pada Wirid Yasin }\end{array}$ \\
\hline 2 & Nasihat & Ceramah Maulid \\
\hline 3 & Keteladanan & $\begin{array}{l}\text { Kata-kata bijak 5 } \\
\text { sebelum mulai belajar }\end{array}$ \\
\hline 4 & $\begin{array}{l}\text { Praktek dan Pembiasaan } \\
\text { dalam Ibadah }\end{array}$ & \\
\hline 5 & Kedisiplinan & \\
\hline 6 & $\begin{array}{l}\text { Shalat Berjamaah setiap } \\
\text { waktu }\end{array}$ & $\begin{array}{l}\text { Bimbingan } \\
\text { Pendampingan }\end{array}$ \\
\hline 8 & $\begin{array}{l}\text { Koordinasi Dayah dengan } \\
\text { Wali }\end{array}$ & \\
\hline 9 & $\begin{array}{l}\text { Koordinasi } \\
\text { Stakeholder }\end{array}$ & dengan \\
\hline 10 & Reward dan Funishment \\
\hline 11 & Out put pembinaan akhlak \\
\hline
\end{tabular}

Pola pembinaan akhlaq santri di pesantren/ Dayah mempunyai keunggulan yang dapat diberlakukan dalam pendidikan siswa disekolah diantaranya : 1. Kejelasan sumber nilai-nilai akhlaq yang ingin dikembangkan berupa kitab standar Dayah yang mepiputi kitab Ta'limul Muta'allim, kitab Daqaikul Akhbar, kitab Muraqi Ubudiyah, kitab Sirajut Thalibin. 2. Kedisplinan pelaksanaan dan praktek, 3. Keteladanan dari para ustadz/ Teungku dan 4. Pengawasan yang terus menerus selama 24 jam sehari.

\section{Kesimpulan}

Berdasarkan hasil pembahasan di atas, penulis dapat menyimpulkan beberapa poin kesimpulan:

1. Terdapat persamaan di semua dayah tentang mata pelajaran pokok yang diajarkan kepada para santrinya. Misalnya pengetahuan hukum Islam (Ilmu Fiqih), tata bahasa (Ilmu 
Nahu dan Ilmu Saraf), Tauhid dan Tafsir. Oleh karena itu, muatan kurikulumnya 100\% ilmu agama, yaitu: al-Qur'an, Tafsir, Ilmu Tafsir, Hadits, Ulum al-Hadits, Tauhid, Fiqih, Ushul Figh, Akhlak, Tasawuf, Tarikh, Bahasa Arab, Nahwu Sharf, Balaghah, Ilmu Kalam, Ilmu 'Arudl, Ilmu Manthiq, Ilmu Falaq, dan disiplin ilmu lainnya. Struktur kurikulum ini menunjukkan bahwa pendidikan pesantren bertujuan untuk mencetak ahli ilmu Agama Islam.

2. Media pembelajaran yang tersedia di dayah terbagi ke dalam dua bentuk media, yaitu media audio dan media non audio. Sampai saat ini pembelajaran di dayah hanya menggunakan media papan tulis, kitab, spidol dan alat tulis lainnya sebagai media pembelajaran bagi santri. Pemanfaatan media audio berupa pemutaran film-film bernuansa Islami melalui infocus, pemasangan soundsystem untuk memutarkan ceramah dan nasihat-nasihat agama, sertaada juga pemanfaatan madding untuk saran informasi.

3. Sampai saat ini khususnya di Aceh, dayah telah diakui atas keberhasilannya dalam membina akhlak santri. Hal ini sangat berhubungan dengan penggunaan metode pembinaan akhlak yang diterapkan di lembaga pendidikan dayah. Metode pembinaan akhlak yang digunakan meliputi: Pertama, pelurusan motivasi, Kedua, metode nasihat. Ketiga, metode keteladanan. Keempat, praktek dan pembiasaan dalam ibadah. Kelima, bimbingan dan pendampingan. Keenam, koordinasi dayah dengan wali. Ketujuh, koordinasi dengan stakeholder. Kedelapan, reward dan funishment. Kesembilan, input keberhasilan pembinaan akhlak.

4. Keunggulan pendidikan akhlaq santri di pesantren yang dapat diberlakukan dalam pendidikan siswa disekolah diantaranya : a. Kejelasan sumber nilai-nilai akhlaq yang ingin dikembangkan berupa kitab standar Dayah yang meliputi kitab Ta'limul Muta'allim, kitab Daqaikul Akhbar, kitab Muraqi Ubudiyah, kitab Sirajut Thalibin. b. Kedisplinan pelaksanaan dan praktek akhlaq, c. Keteladanan dari para ustadz/ Teungku dan d. Pengawasan yang terus menerus selama 24 jam sehari.

Pembinaan akhlak maupun karakter harus benar-benar komitmen diterapkan di lembaga pendidikan, karena bila di 
lembaga pendidikan saja sudah hilang akhlak pelajarnya, maka suatu saat bila pelajar tersebut masuk ke dalam dunia kerja, sungguh akan sulit memperbaiki akhlaknya

\section{Daftar Pustaka}

Ahmad Naufah, 2011. Ikhtiar Pelajar dan Santri Menjaga Degradasi Moral, (Makalah pada Seminar Nasional), Yogyakarta

Abdullah, Taufiq dan Rusli Karim, 1999. Metodologi Penelitian Agama Sebuah Pengantar, Yokyakarta: Tiara Wacana.

Abdurrahman An-Nahlawi, 1996. Ushulut Tarbiyah Islamiyah Wa Asalibiha fii Baiti wal Madrasati wal Mujtama' (Penerjemah. Shihabuddin), Jakarta: Gema Insani Press

Ahmad Dimyathi Badruzzaman, 2004. Panduan Kuliah Agama Islam. Bandung: Sinar Baru

Ahmad D. Marimba, 1990. Pengantar Filsafat Pendidikan Islam, Bandung: Al Ma'arif

Ajat Sudrajat, et.al, Din Al Islam, 2008. Pendidikan Agama Islam di Perguruan Tinggi Umum,Yokyakarta; UNY Press

Bambang S, 1996. Kerangka Pengembangan Pendidikan Tinggi, Jakarta, Dikti.

Departemen Pendidikan dan Kebudayaan, 2003. Kamus Besar Bahasa Indonesia, Jakarta: Balai Pustaka

Database Mahasiswa Sekolah Tinggi Agama Islam (STAI) AlAziziyyah Samalangan, Bireuen.

Husni Nasution, 2001. Arah Baru Pendidikan Islam di Indonesia, Jakarta; Logos.

Ismail, Azman, 2007. Syariat Islam di Nanggroe Aceh Darussalam”, Banda Aceh: Dinas Syariat Islam Aceh.

Kamaruzzaman Bustaman-Ahmad, 2007. "The Application of Islamic Law in Indonesia; The Case Study of Aceh" International Journal Of Indonesian Islam-Australia. Vol 01, Number 01. 
Moleong, Lexy J. 2000. Metodologi Penelitian Kualitatif, Bandung: Remaja Rosdakarya.

Muhammad bin Ibrahim al- Hamd, 2002. Maal Muallimin, (Penerjemah, Ahmad Syaikhu), Jakarta: Darul Haq

Musliadi, 2012. Peran Dan Tanggung Jawab Ulama Dayah Dan Akademisi Dalam Mencegah Kekerasan Di Aceh, (Makalah).

M. Athiyah Al Abrasy, 1970. Dasar-dasar Pokok Pendidikan Islam, (terj. Bustami A. Ghani dan Djohar Bahry L.I.S), Jakarta: Bulan Bintang

Nurochim, Sekolah Berbasis Pesantren Sebagai Salah Satu Model Pendidikan Islam Dalam Konsepsi Perubahan Sosial, Jurnal Al-Tahrir Vol 16, No 12016

Nur Uhbiyati, Manajemen Pelaksanaan Kurikulum Pondok Pesantren Salaf Al-Fadlu Kaliwungu, Kendal, Vol. XI (Semarang; UIN Walisongo; 2012

Omar Muhammad al-Toumy Al-Syaibany, 1979. Filsafat Pendidikan Islam, (terj. Hasan Langgulung), Jakarta: Bulan Bintang.

Saifullah, 2003. "Kelebihan Pendidikan Berbasis Dayah", (Serambi Indonesia)

Silahuddin. Budaya Akademik Dalam Sistem Pendidikan Dayah Salafiyah Di Aceh, Vol. XL. Medan; UIN Sumatera Utara, 2016

Suharsimin Arikunto, 2002. Prosedur Penelitian Ilmiah Suatu Pendekatan Praktis, Jakarta: Reneka Cipta.

Yunahar, 1999. Kuliah Akhlak, Yogyakarta: Pustaka Pelajar offset

Zamakhsari Dhofier, 1985. Tradisi Pesantren: Studi Tentang Pandangan hidup Kyai, Jakarta: LP3ES

Zuhairini, dkk., 1983. Metodik Khusus Pendidikan Agama, Surabaya: Usaha Nasional 
Zulkarnaini dkk, 2011. Menelusuri Pelaksanaan Syariat Islam; Gagasan dan Pelaksanaan di Wilayah Timur Aceh, Banda Aceh: Dinas Syariat Islam Aceh 